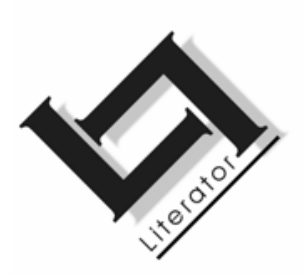

\title{
Mystery in Sepedi detective stories
}

\author{
M.J. Mojalefa \& N.I. Magapa \\ Department of African Languages \\ University of Pretoria \\ PRETORIA \\ E-mail: jerry.mojalefa@up.ac.za
}

\section{Abstract \\ Mystery in Sepedi detective stories}

The aim of this article is to illustrate the importance of the concept "mystery" in the classification of Sepedi detective stories. Mystery is therefore first defined, and then some rules governing how mystery is created and sustained in a narrative are reviewed. Examples are given of how the writers of Sepedi detective stories mislead their readers in order to create mystery. Mystery is then examined according to five of its constituent elements, namely the real character of the detective, the name of the criminal, the identity of the victim, the evidence that reveals the mystery in the end, and the investigation that reveals the mystery. Each category is explored by citing relevant examples from Sepedi detective stories.

\section{Opsomming}

\section{Die raaisel in Sepedi speurverhale}

Die doel van hierdie artikel is om die belangrikheid van die konsep "raaisel" in die klassifikasie van Sepedi speurverhale te illustreer. Die raaisel word eers gedefinieer en daarna word 'n oorsig gegee van die reëls wat die skep en voortbou van die raaisel onderlê. Voorbeelde word verskaf van hoe Sepedispeurverhaalskrywers lesers doelbewus mislei om daardeur raaisels te skep. Die raaisel word vervolgens bestudeer aan die hand van vyf onderliggende elemente, naamlik die ware karakter van die speurder, die naam van die misdadiger, die identiteit van die slagoffer, die bewyse wat daartoe lei dat die raaisel aan die einde ontrafel word en die ondersoek wat die raaisel aan die lig bring. Elke kategorie word ondersoek deur die verwysing na gepaste voorbeelde uit Sepedi-speurverhale. 


\section{Introduction}

A review of the relevant literature shows that thus far only eight researchers and literary theorists have attempted to analyse Sepedi detective stories, namely Mahole (2002), Mojalefa (2001), Magapa (1997), Machiu (1995), Groenewald (1993b), Mampuru (1986), L.L. Mphahlele (1984) and Serudu (1984).

Mahole (2002) emphasises the structure of the Sepedi detective story, while Machiu (1995) examines the characteristic features of a Sepedi detective story, namely exposition, development, climax, and denouement. Magapa (1997) compares two of Lebopa's detective short stories, and L.L. Mphahlele (1984) compares Tšhipu e rile ke lebelo (1962) by D.N. Moloto and Lenong la Gauta (1982) by H.D.N. Bopape. Serudu (1984) and Mampuru (1986) both describe the relationship between setting/milieu and characters. Groenewald (1993b) and Mojalefa (2001) briefly investigate the classification of Sepedi detective stories.

Thus, to date, no thorough investigation of mystery in a detective story in Sepedi has been made. Therefore, this article focuses on the use of mystery in Sepedi detective stories.

\section{Mystery in a detective story}

Mystery is an important feature of detective stories, and before it can be examined it must be carefully defined. Various literary theorists have attempted to describe the concept of mystery. Turco (1999:59) says that mystery focuses on the suspense and tension present in a detective story. This suspense arises because the reader of the story wants to know how the conflict evident between the protagonist and antagonist is going to be resolved; this conflict has a mysterious cause, and so for the conflict to end, the mystery has finally to be revealed. Boileau and Narçejac (1964:8) note that the aim of the investigation depicted in a detective story is to solve a mystery (usually a crime) that seems impossible to solve at the beginning of the story.

Shapiro (1979:553) concurs stating that a mystery story has a main character who is not a professional detective. The reader sympathises with this hero. In such a story there may or may not also be a police officer who solves the mystery or helps the main character to do so; sometimes the police officer saves the hero from danger at the climax of the plot, as part of the dramatic resolution of the 
mystery. At other times the mystery is solved through patient deduction.

Lazarus and Smith (1983:86) stress the manner in which the detective hero reconstructs how and why the crime was committed, and he finally arrests the criminal, thus revealing the mystery. Therefore, the concept of mystery is important, because it functions to make the detective story readable; it intrigues readers.

In investigating the concept of mystery in Sepedi detective stories, attention will be given to four elements, namely the investigator/detective, the criminal/murderer, the victim/murdered, and the evidence. A fifth element, namely the investigation, is important in clarifying the mystery created by the first four elements. Groenewald (1993b:30) proposes these five elements as useful focal points in an examination of the mystery to be revealed at the end of a detective story. He builds on the work of Boileau and Narçejac (1964:8), who only mention the first four elements.

Overall, then, when the concept of mystery is referred to in this article, this implies a complexity of ideas, which can be set out in the following scheme:

- The real character of the investigator, which is a mystery

- The name of the criminal/murderer, which is a mystery

- The name of the victim/murdered, which is a mystery

- The evidence that reveals the mystery at the end

- The investigation that reveals the mystery

These five elements will form the structure of this article, and each will be examined in some detail, with an example of a Sepedi detective story that centres on that particular element. Before examining this scheme more closely, certain aspects of the guidelines governing how the mystery is used in a detective story and the techniques involved in elevating mystery will be explored.

\section{Rules of writing a detective story to emphasise mystery}

When readers start reading a detective story, they are already well aware of the fact that some sort of crime has been committed, and that this has to be solved. They also know that the criminal has to be caught and punished accordingly. Haycraft (1942:252) stresses this as a vital aspect of a detective plot; the criminal who hopes to 
benefit by the crime cannot escape, and has ultimately to be exposed.

If consequences are inescapable, this seems to leave us with a paradox; why then does the author of a detective story go to the trouble of creating a mystery at all, since the final disclosure is assured? Suits (1985:205) provides an answer to this question, alluding to the fact that the author of a detective story, as with a player in any given game, has to comply with the rules that govern this genre. In the examination of the work of Willard Huntington Wright (alias S.S. van Dine), Palmer (1978:93) also made this point, saying that the author of a detective story has to fulfil these rules because "the detective story is not really fiction, but ... a complicated and extended puzzle cast in fictional form".

According to Todorov (1988:168), this idea of the detective story as a "complicated and extended puzzle in fictional form" originated with S.S. van Dine in 1928, when he drew up twenty "rules" governing how a detective story should be written. Van Dine writes that any self-respecting author of detective stories, who wishes to uphold the reputation of the genre, has to respect these rules. (A full examination of these rules is beyond the scope of this article, but where relevant, some of them will be cited in the examination of individual stories.)

At times authors seem to deviate from these rules, for example, including romantic sub-plots that can obscure the central detective focus. However, when well used these love stories simply function to complicate the mystery, thus further arousing the readers' interest. These stories can be called a sub-genre of the detective story genre. Mystery is there, but in a disguised manner. An example of this sub-genre is Kekana's Nnete Fela (1989).

This highlights the guiding principle behind Van Dine's rules: they all function to heighten the readers' interest, to encourage them to read further. Winks (1980:5) points out that the crime itself actually functions to arouse the readers' interest, because once the crime has been committed the mystery of who did it is created, and the readers look forward to the solution of this mystery. This inquisitiveness about what happened and how it happened helps sustain reader interest.

The final important aspect of these rules of writing a detective story concerns the author's ability to maintain the mystery until the investigation has been completed and the solution can be revealed. 
Groenewald (1977:19) indicates that the author can follow two possible routes in order to maintain the mystery. The first route is to present vital information in such a way that the readers do not realise that it is important until the end of the plot and the second is to keep readers in suspense by withholding vital information until the criminal has been revealed.

Winks (1980:17) quotes Auden, who says that the crime of murder is an unique act, because it terminates the life of the victim so that the community has to take the place of the victim and ensure that the murderer is punished.

The function of all these rules are to help authors create suspense, concealing the mystery until the end of the story. One of the main routes to achieving this, as mentioned above, is deliberately misleading the reader. Because this aspect will be focussed on in an examination of individual Sepedi detective stories, techniques to mislead readers will now be examined in more detail.

\section{Misleading the readers in order to create mystery}

The various methods the author uses to enhance the mystery can be referred to as techniques. Groenewald (1993b:31) argues that these techniques usually function to conceal the investigator's thoughts from the readers. An important technique, used by a number of authors, including Agatha Christie, is to employ a minor character as narrator, who then describes the investigator's actions to the reader. Shipley (1970:78-79) notes that this narrator in a detective story tends to hero-worship the investigator, and that this hero-worship is the motivating factor behind the narrator's storytelling. Groenewald (1993b:31) adds to this, noting that readers are often led to regard the investigator as highly intelligent and the narrator as less intelligent.

A narrator, according to Prince (1988:65), is "the one who narrates", and according to Wales (1989:316), is "the person who narrates". Bal $(1985: 119)$ on the other hand, emphasises that the narrator is "the director of the story", a tool with a specific function. In a detective story, this function is to create mystery; the minor character, through his/her narration, keeps the readers in the dark about what the investigator is actually thinking. Therefore, deploying dramatic irony, the reader and the narrator are in equivalent positions of ignorance, neither knowing much about the investigator's actions, whereas the investigator knows fully. Groenewald (1993b:31) states the author uses the narrator as a "limited point of view" technique in 
order to derail readers. The first author to use this technique is Arthur Conan Doyle, in A Study in Scarlet (1887). In this book he creates the pseudo-biography of Sherlock Holmes, using a narrator, Dr. Watson. Doyle's use of Dr. Watson has influenced many writers and literary critics of detective stories.

Groenewald (1993b:31) notes that when an author uses this kind of narrator to derail readers, he/she actually writes two stories. The first story is that of the narrator; this story is only partly true because the narrator does not know the full truth, but this is only known to the investigator and the author. The second story is that of the investigator/detective, and contains the full truth.

Therefore, it is clear that authors can use this type of narrator to conceal the mystery from their readers. Because of the narrator's lack of knowledge, which the readers share, the readers can sometimes doubt the character of the investigator as his/her superior knowledge can appear almost supernatural. This can lead to readers feeling alienated. For this reason, Groenewald (1984:6) argues that detective stories should rather use a first person narrative voice, that of the investigator, so that readers can identify with the investigator who knows the whole truth, rather than with another character who is shown to know very little. Haycraft (1942: 234) argues against this, saying that seeing the story through the eyes of an omniscient narrator, whether this is the investigator or what he calls "the omnipotent angel", will only annoy readers. Groenewald (1993b:31) argues the opposite, saying that there is nothing more pleasing to readers than to experience the revelation of the mystery simultaneously with the investigator, together with the surprise and wonder that accompanies this revelation.

The problem as to whether it is possible to keep the reader and investigator equally informed while still maintaining the mystery until the denouement, however, remains. Groenewald (1993b:32) cites an example of a successful first-person narrator in a detective story, namely Heimito von Doderer's Ein Mord den leder begeht ( $A$ murder involving everyone) (1964). This book is usually classed as a family story, but the plot involves a crime (in this case a murder) that warrants investigation to reveal the mystery. Groenewald thus argues that this can be considered a detective story. The main character perforce becomes the investigator, but because he is unaware of his role, his actions put a succession of other people under suspicion, thus maintaining the suspense. When, in the end, he solves the mystery, the surprise is total, because he is the narrator and so he and the readers experience the resolution to- 
gether. On the basis of this example, Groenewald argues that it is possible to maintain suspense even when using a first-person narrator, by complicating the plot so that the mystery is not easily solved.

\section{Astonishing and calming the reader}

The fifth element that can create mystery in the detective story, as mentioned in the list above, is the investigation that reveals the mystery. Groenewald (1993b:32) argues that this element functions firstly to astonish and then to calm readers. The astonishment arises from the process of investigating the mystery. A detective story, as mentioned above, revolves around the crime that has been committed; there is no mystery here, because readers and investigators alike know that the crime has been committed. The mystery lies in the identity of the criminal. What astonishes readers is the various details of the investigation, such as when the investigator faces danger and may even have to risk his/her life, or when the investigator as a private individual becomes a suspect in the official police investigation. Though the process of investigation does cause astonishment along the way, in the end, however, it brings calmness to the readers, because it is the mechanism through which the mystery is solved and the criminal caught or punished. Other features of plot help to maintain readers' interest through the investigation, for example romantic sub-plots.

Following this background on the techniques and elements of detective fiction, the discussion moves to examining the detective story in Sepedi.

\section{The detective story in Sepedi}

By 1998, only twenty-two detective stories had been published in Sepedi, twelve of which are short stories. These are Tšhipu e rile ke lebelo (Moloto, 1962), Lenong la Gauta (Bopape, 1982), Leabela le a fetiša (Maphoto, 1983), Letlapa la Bophelo (Moloto, 1983), Nonyana ya Tokologo (Kekana, 1984), Etshwang Mare (Mothapo, 1986), Nnete Fela (Kekana, 1989), Sesasedi sa katlego (Kekana, 1990), Ga se nna mmolai (Maputla, 1991), and Kepisi ya lephodisa (Mojalefa, 1998). The following are examples of detective short stories in Sepedi: "Tšhelete ya sepoko" and "Moloi ga a na mmala" from the collection Molomatsebe (Ramaila, 1951), "Serapeng sa Badimo" from the collection Hlokwa-la-tsela (Matlala, 1969), "Ralato 1-5" from the collection Nka se lebale (Motuku \& Ramokgopa, 1972), "Tšhipu e rile ke lebelo" from the collection Seswai sa dita- 
banatodi (Ngoepe, 1980), "Moloko ga o fahlwe ka moka" from the collection Lerole la Bjaša (Tlooke, 1987) and "Bomahlwabadibona" and "Ntlo ya monna yo mongwe" by P.M. Lebopa from the collection Makhura' lefehlo (Mampuru, 1991).

The aim of this article is not to illustrate mystery in all of these twenty-two pieces, but to cite one example to represent each of the sub-genres of the detective stories in Sepedi.

\section{The character of the investigator is a mystery}

Attention is focused on the complex of mysterious elements mentioned earlier, starting with the character of the investigator. In this sub-genre, the detective short story "Serapeng sa Badimo" ["At the graveyard/garden of the ancestors"] by Matlala (1969) is investigated as a typical example. This examination focuses at first, on the mysterious element in this detective short story, and then on how the author arouses interest among readers.

\subsection{Mystery in "Serapeng sa Badimo"}

This detective short story centres on the mysterious character of the investigator. Matlala portrays the protagonist, Maoke, as an antagonist, is an ordinary man fraudulently pretending to be a diviner, thus succeeding in blinding readers and creating mystery in this story.

Matlala blinds his readers by portraying the investigator in an indirect manner. Firstly, when the murder is committed, a diviner appears to investigate, rather than the police. The diviner goes around with his bones as if he is going to solve the problem with their help, but in fact he is just carrying them to disguise his real character. Maoke thus appears as an evil character, rather than the investigator expected in a detective story. His initial failure to solve the mystery tricks readers into looking with interest to see what the next step is going to be, and who the real investigator will be. However, when in the end Maoke convinces the Chief that the ancestors have revealed to him who Lamola's murderer is, readers realise with a shock that this fraudulent diviner has been the investigator all along. In this way, the true character of the investigator has been a mystery from the beginning of the plot, until the end, when the evidence revealing the mystery is made known.

Matlala's technique of concealing the true character of the investigator through effectively blindfolding the reader is actually a 
strategy to heighten readers' interest in his book. The technique used in this detective short story to intrigue readers is now examined in more detail.

\subsection{Techniques for arousing reader interest in "Serapeng sa Badimo"}

Readers' interest is aroused by conflict. Kgatla (2000:102) describes conflict as contradictions visible among the characters of a short story, novel or drama. Holman and Harmon (1960:118) call it a growing contest between the two conflicting sides of the plot. In a detective story, conflict is between good and bad. This conflict is central to the suspense of the plot, and thus to the readers' interest.

The conflict of a plot has to be developed, in order to develop the readers' interest. Groenewald (1993a:16) describes interest as that which appeals/forces the reader to continue reading, out of a desire to know what happens and understand the author's message. Magapa (1997:14) therefore points out that this interest is caused by the interface of knowledge and lack of knowledge.

An author stimulates interest in readers using narrative techniques. Groenewald (1993a:17) explains technique as the authors' tool to unfold theme, and says that technique has two roles: firstly to emphasise, develop and confirm an opinion, and secondly to relate this opinion to a theme. Mojalefa (1995:24) states that techniques are the straight or crooked routes the author uses to tell the story.

These definitions are rather general. On a more focused level, an important technique found in "Serapeng sa Bodimo" is the description of the protagonist as an antagonist in order to heighten readers' interest. The protagonist is the main character of a story, and in the case of a detective story is also the investigator. Groenewald (1993a:16) describes the investigator of a detective story as an intelligent, well behaved person without weaknesses and who is respected by the other characters. The antagonist, according to Baldick (1980:10-11), is a complete contrast to the protagonist, a person constantly against the hero of the story. In a detective story, the antagonist is usually the criminal. This category is sometimes problematic, because at times the antagonist may be a good person, forced into the antagonistic role by adverse circumstances.

As mentioned above, conflict arouses the interest of the reader. To keep the readers' knowledge and lack of knowledge in a balance of tension, to maintain the conflict, the author may keep the protagonist 
and the antagonist at loggerheads throughout the plot. This sustains readers' interest. This technique of creating conflict will be explored in "Serapeng sa Badimo", after two more examples of techniques have been examined.

\subsection{Conflict in "Serapeng sa Badimo"}

In this detective short story, interest is also aroused by the conflict between good and evil. Lamola, a rich man from Dibaneng Village, represents the good, whereas his murderer, whose name remains a mystery until it is revealed towards the end of the story, represents the bad. Lamola's death arouses interest in readers because in this event good and bad are in conflict. Readers would like to know the identity of Lamola's murderer, but the author keeps this a mystery. As a result, readers read further and further in order to find out the resolution of the mystery.

What makes this story more interesting is that even the famous diviner, Maoke, seems unable to solve the problem with his divining bones. Matlala presents Maoke's failure in order to sustain the reader's interest. This failure then causes conflict between Maoke and the Chief. Readers want to know what will happen next: will the Chief chase Maoke away or will he look for help from the police? What consequences will his chasing away of Maoke have? These are some of the questions readers are led to ask as they read further.

Another event that arouses interest in "Serapeng sa Bodimo" is the meeting of all the village men at the Chief's kraal, for a ritual anointing of their axes with muti before they gather branches for building the "god's kraal". Some men fail to arrive for this meeting, and their absence arouses suspense. What punishment will the Chief impose on these men? What if they do not come to the kraal even after a second summons? This addition conflict also arouses the readers' interest.

The use of the protagonist and antagonist is now examined in this detective short story to evaluate their success or failure in arousing or sustaining the interest of the readers.

\subsection{The investigator protagonist in "Serapeng sa Badimo"}

With the character of Maoke, Matlala creates many opportunities to heighten conflict. Maoke the diviner is an intelligent person, whom readers like because he is presented as a popular and useful man in 
the Chief's kraal. However, as mentioned above, when his bones fail to reveal the identity of Lamola's murderer, Maoke's credibility among readers begins to crumble. This loss of credibility is worsened by the revelation that Maoke is a charlatan; that he is not in fact a trained diviner. Maoke's intelligence brings this conflict to a peak, because when the Chief finally demands results from the bones, Maoke comes up with the trick of impersonating the gods. Readers wait in anticipation to see the success or failure of this ruse, and are finally satisfied when the Chief is convinced by Maoke's trick.

\subsection{The criminal antagonist in "Serapeng sa Badimo"}

Throughout this detective short story, readers are kept in suspense as to the identity of Lamola's brutal murderer. This suspense is heightened by the positive presentation of Lamola, a rich and virtuous man. The readers' interest is maximised by the withholding of even the smallest clue about the criminal antagonist's identity. Over and above this, Matlala let Maoke's bones fail him and he is unable to reveal the criminal. Matlala also describes how Mathuba's son picks up an axe covered with blood while wandering in the field. The reader would like to know whose axe it is, and how this is going to be revealed. The failure of Maoke's first trick also arouses interest further, as does the Chief's command that all the men must bring their axes to the kraal. Readers immediately begin to wonder what the intention of this command is. In the end, it turns out that Maoke has cleverly summoned the men bring their axes so that he can identify the criminal. Lamola's murderer had thrown away his axe at the scene of the crime and thus have to bring a new one, which is easily identifiable.

In conclusion, "Serapeng sa Badimo" centres on a mystery related to the character of the investigator protagonist. Matlala uses the diviner Maoke as the investigating protagonist. Although he is honoured and respected by the Chief as a diviner, Maoke does not solve the mystery using his bones, but rather through his uncanny intelligence. Matlala's character portrayal and use of conflict reflect maturity and effectively arouse the interest of the reader.

\section{The identity of the criminal is a mystery}

The discussion moves to an investigation of the next element of mystery, namely the name of the criminal. An example of a detective story centred on this element is the novelette Tšhipu e rile ke lebelo (1962) by D.N. Moloto, which is representative of books falling into 
this sub-genre. The ramifications of keeping the name of the criminal unknown and therefore mysterious is first explored.

\subsection{Definition of a criminal}

Haycraft (1942:254) states that there must be one main criminal who is a convincing human being in the detective story. This criminal has to be very intelligent. Haycraft thus implies that even if the crime is committed by a group of people, there must be a mastermind among them, one who must be presented as a human being with feelings and who is of equal intelligence to the investigator so that they can compete with each other.

The technique to maintain the conflict vital in order to keep a story interesting is already discussed, namely for the antagonism to oppose characters - in a detective story this antagonism is usually between the investigator and the criminal. Both these characters are present throughout the plot to keep readers interested. The question is then, how does Moloto manage to keep the identity of the criminal a mystery in the novelette Tšhipu e rile ke lebelo (1962), while successfully building antagonism between the investigator and the unknown criminal? Major techniques used in the novelette include arousing reader interest and misleading readers. These can be further explored.

\subsection{Arousing reader interest and misleading readers in Tšhipu e rile ke lebelo}

Interest can be aroused and misleading impressions also created through naming. Baker (1997:15) and Shipley (1970:129) note that the name of a character gives the reader a picture of the character. Moloto, for example, gives his gangster character the name of a poisonous snake, Cobra, to create a vivid impression of an evil person, which in turn arouses readers' interest. Moloto does this in order to mislead his readers as to who the real criminal is. A careful reader will notice that horrible things continue to happen even during the absence of this gangster, so that despite appearances there must also be another criminal, a criminal whose name is kept hidden. By doing this, the author tantalises readers to read further with the intention of finding out who this person is and how he/she is going to be arrested.

The use of names is also combined with other techniques to arouse reader' interest. When Makhina overhears the gangster and Hlogotšhweu coming up with a plan to do away with him, this further 
arouses interest. What will Makhina do now that he knows of the plot against him? This technique interacts with the use of names, because this incident strengthens the impression created by Cobra's name, and thus the final realisation that Cobra is not actually the murderer becomes even more shocking. This is the real cause of interest.

\section{The name of the victim is a mystery}

An example of a Sepedi detective story centred on the mysterious identity of the victim is examined next. A short story by P.M. Lebopa, "Ntlo ya monna yo mongwe", from the collection Makhura' lefehlo, edited and arranged by Mampuru (1991), is such a story.

\subsection{Definition of a victim}

Auden as cited by Winks (1980:19) stated that the victim has elements of both of the opposing sides, the good and the bad, because he/she is a weak character. Serudu (1985:120) adds that the victim should not be a criminal because this would place him/her in conflict with the law.

These characteristics are clearly shown by the victim in "Ntlo ya monna yo mongwe", who is called Tumo (which literally means fame). Tumo is an ordinary person, with a clear weakness: he is incapable of thinking for himself, so readers tend to despise him, although he is a likeable character.

The extent of Lebopa's success in creating a story around a mysterious victim is examined in mystery in "Ntlo ya monna yo mongwe", and techniques to arouse interest and mislead readers in "Ntlo ya monna yo mongwe".

\subsection{Mystery in "Ntlo ya monna yo mongwe"}

Mystery in this detective short story centres on the mysterious victim. The plot functions to prevent readers from realising that the victim is a character already known to them and liked by them. This mystery begins with the title of the story, which is a shortened version of a Sepedi idiom. In its complete form the idiom reads "Ntlo ya monna yo mongwe ga e na boroko", which literally means "there is no peace in another man's house". This is a hint to readers that something unfortunate and unusual is going to happen towards the end of the story. The antagonist in this story conceals mystery from both the protagonist and the readers, as is suggested by the full 
version of the idiom quoted above. The idiom suggests the problematic reasons lying behind divorce, and thus readers are warned that the relationship between Vincent and Shadi is more complicated than one might expect.

The police investigation of course reveals the murder, and so the mystery of the victim's name is made central right at the beginning of the story. When events reach a climax, readers realise that Shadi is not the victim, the innocent woman whose two husbands have been murdered, but rather that she is the criminal, who has used Vincent and Tumo to kill for her, so that she can keep her hands on the wealth of her husbands. Thus, Tumo is a victim of Shadi's greed; his name has been kept a mystery. From the beginning readers like him because of his kindness. This is the climax of the plot, because with this revelation the mystery is solved and the suspense dispelled.

\subsection{Techniques to arouse interest and mislead readers}

Lebopa uses multiple techniques to keep readers interested, and to mislead them. He uses misrepresentation, presenting Vincent as the antagonist initially and only later reveals that Shadi is the real problem; repetition of the meeting between Shadi and Tumo, and the visit of Pheladi to Shadi; and also shifting of the chronological events in the plot from the beginning to the end of the story and vice versa. All these techniques function to derail readers' expectations and surmises, thus making the story more exciting.

The mystery vital to the success of this detective short story is that of the identity of the victim. The author first introduces this mystery by using an incomplete title for the short story. Secondly, he cleverly plays with the characters' roles as protagonist and antagonist to create suspense. As suggested above, Shadi appears in the beginning to be the positive character, the protagonist, and Vincent and Tumo the antagonists, but in the end it turns out that the opposite is the case. Shadi is wicked and she uses the two men for her own needs.

\section{The evidence reveals the mystery}

The fourth element of mystery, namely, the evidence that reveals the mystery at the end, is now elaborated upon. The detective novel Lenong la Gauta (1982) by Bopape is used to represent detective stories falling into this sub-genre. 


\subsection{Definition of evidence}

La Cour and Mergenson (1971:120) and Mandel (1984:16) agree that the evidence must astonish the detective and the readers at the close of the plot. This astonishment has to be produced by the deceptive presentation of evidence during the story so as to maintain the mystery till the resolution of the plot. Grella (1980:86) emphasises that cheating is involved in the presentation of the evidence to readers in the course of the plot. Because readers are usually supposed not to be of equal intelligence with the investigator, the readers cannot solve the mystery but the investigator can. Grella, however, stresses that the final revelation, brought about by the linking of the evidence with the criminal, astonishes both investigator and readers. Thus the evidence, cleverly presented to maintain the mystery derails readers' expectations and powers to deduction. Sayers (1989:31) calls this manner of derailing readers "the art of telling lies", and says that from the beginning to the end of the detective story it is the intention of the author to derail readers. For example, the author can initially present the murderer as a good person. Similarly, the author can present vital evidence openly to the readers at the beginning of the plot, but tempt readers to consider it of minor significance until the climax of the plot has been reached and the true importance of the evidence revealed. Examples from Lenong la Gauta include the mud on the tyres, described at the beginning of this detective story, and Brenda's refusal to let her husband, Nnono, touch her on the neck. These examples are explored in more detail, in order to determine how effectively Bopape exploits evidence as the element of mystery in his construction of Lenong la Gauta.

\subsection{Mystery in Lenong la Gauta}

Mystery in this detective story is maintained largely by clever presentation of evidence. Bopape uses evidence to mislead in two main examples, mentioned above. On the first page of this detective story, Bopape talks of mud on the tyres of Brenda's car. This mud surprises the narrator, who is the investigator, Nnono Molaba, and readers may wonder where this mud has come from. When the death of Mmatšhego is announced, readers suspect Brenda, but have no evidence, other than the mud, to link Brenda to this murder. The irony about this evidence is that it is the readers who suspect Brenda, not Nnono, the investigator. Nnono knows from the information he has received from the police investigation that the suspect must have fresh scratch marks on the right side of the face, caused by the deceased in their struggle. Groenewald (1993b:34) 
points out that the concluding evidence is cleverly withheld until just before the climax. This evidence is the fresh scar on the right side of Brenda's neck. According to Groenewald, this is where the second mystery comes into being; how will the scars be seen because they are covered with clothing? This mystery is revealed when inadvertently Brenda takes off her clothes and Nnono sees the scars, and thus recognises Brenda as Mmatšhego's murderer. The author actually suggests both these mysteries through the narrator right at the beginning of the plot, but only indirectly. This indirect revelation is a technique that the author uses to arouse the readers' interest. Had Nnono Molaba understood why Brenda would not let him touch her neck, the mystery of Mmatšhego's murderer would have immediately been solved. Nnono would not then have been manhandled and checked thoroughly by the police, a scene that greatly increases the excitement of the story. Therefore, Bopape conceals the mystery that he has in fact presented openly to the reader in order to maintain suspense and excitement, and also to satisfy one of the requirements of the evidence in a detective story, as is explained later.

\subsection{Techniques to arouse interest and to mislead the reader}

Bopape shows a great deal of experience and maturity in the number of techniques he uses to arouse interest, always with the aim of misleading readers to heighten their interest. He uses thirty-two distinct techniques, two of which are explored in more detail.

The first techniques is the use of complication of events. Events that take place at the beginning of the story are put at the end, whereas events that take place at the end of the story are put right at the beginning. In this way, Bopape easily arouses interest and misleads the reader. The second technique is the use of tension and suspense as interwoven techniques. For example Kwete reports to Nnono the situation and position in which he finds Mr. and Mrs. Maleka, causing tension and suspense not only in Nnono but also in the readers.

\section{The investigation reveals the mystery}

The final element of mystery that classifies Sepedi detective stories into sub-genres, namely, the investigation that reveals the mystery, is explored. Examples are drawn from M.A. Kekana's Nnete Fela (1989) to represent the works falling into this sub-genre. 


\subsection{Definition of investigation}

Most authors of Sepedi detective stories combine love and humorous affairs with mystery in their stories. Machiu (1995:58) notes that some theorists insist that love and humorous affairs have no place in a narrative about an investigation. Doyle, cited in Murch (1968:12), says that authors may use love or humour only if this does not affect the smooth flow of events in the detective story. He does, however, allow that sub-plots can help to unearth the theme and plot of the narrative, and can also function to lighten the tone of the work, and to reveal the humanity of the investigator.

Humour and romance, if wisely used so that they do not affect the flow of investigation, definitely help to arouse readers' interest, tempting them to continue reading until the investigation is concluded and the mystery revealed. Kekana's use of this technique is now examined in Nnete Fela.

\subsection{Mystery in Nnete Fela}

Mystery in this detective story is set in motion by the cruel acts of the members of a crime syndicate. According to Groenewald (1993b:34), all detective narratives centring on the investigation that reveals the mystery tend to feature antagonists who are strong and hardened criminals. These criminals, who usually work in groups, also employ other people to carry out their criminal acts. Groenewald further notes that such stories include the features of sadness, pursuit and threats. The main issue the reader focuses on is the cruel activities of this criminals and how the investigation is going to reveal the mystery created by these criminals. Whether this investigation is conducted by a professional or an amateur is not important, but rather that the investigator should at the end reveal the mystery caused by these criminals, which is what happens when Ariel escapes their attempts to kill him and brings them to justice.

\subsection{Steps to arouse interest and mislead readers}

Kekana shows that he has a lot of experience in the writing stories of this genre. Right at the beginning of the plot he introduces the main characters with whom the reader are going to travel the route of this detective story, namely Ariel and Bubbles. Kekana uses nineteen techniques to arouse his readers' interest and to mislead them, including complication of events, repetition of events, and foreshadowing. A couple of examples serve to illustrate these techniques. Foreshadowing is illustrated in the conflict between Ariel and 
Bubbles at their first meeting in the commissioner's offices. This confrontation foreshadows or foretells of the struggles between Ariel and Bubbles as they try to find a way to reconcile their love with their other loyalties. This first meeting is echoed when they meet again, soon after, in the parking lot of the office building. This repetition of events is an indirect indication to readers that from now on these two characters will be seeing each other frequently.

\section{Conclusion}

For a detective story to be effective, mystery has to be the most important and thus most characteristic feature of any example of the genre. The most important elements that can create mystery are the real character of the investigator, the name of the criminal, the name of the victim, the evidence that reveals the mystery in the end, and the investigation that solves the mystery.

Although there are few detective stories in Sepedi in comparison to other genres, such as love stories, educational/didactic stories, moral stories, cultural stories or tragic stories, this article has discovered that a fair number of authors have written successful detective stories in Sepedi - stories structured around the five elements of mystery listed above.

\section{List of references}

BAKER, D. 1997. Writing a romantic novel. Chicago: NTC.

BAL, M. 1985. Narratology: introduction to the theory of literary terms. Toronto: Holt, Rinehart \& Winston.

BALDICK, C. 1980. The concise Oxford dictionary of literary terms. New York: Oxford University Press.

BOILEAU, S.A. \& NARÇEJAC, T. 1964. Le roman policier. Paris: Payot.

BOPAPE, H.N.D. 1982. Lenong la Gauta. Pretoria: Van Schaik.

GRELLA, G. 1980. The hardboiled detective novel. (In, Winks, R.W., ed. Detective fiction: a collection of critical essays. Englewood Cliffs: Prentice Hall. p. 103-120.)

GROENEWALD, P.S. 1977. Die speurverhaal. Studies in Bantoetale, 4(1):1945. (Publikasie van die Departement Bantoetale van die Universiteit van Pretoria.)

GROENEWALD, P.S. 1984. Lenong la Gauta by H.D.N. Bopape. South African journal of African languages, 3(2):2-9.

GROENEWALD, P.S. 1993a. Thutadingwalo ya Sesotho sa Leboa, 1. Pretoria: Via Afrika.

GROENEWALD, P.S. 1993b. Thutadingwalo ya Sesotho sa Leboa, 2. Pretoria: Via Afrika.

HAYCRAFT, H. 1942. Murder for pleasure. London: Davis.

HOLMAN, G.H. \& HARMON, W. 1960. A handbook to literature. London: MacMillan. 
KEKANA, M.A. 1984. Nonyana ya tokologo. Johannesburg: Educum.

KEKANA, M.A. 1989. Nnete Fela. Johannesburg: Educum.

KEKANA, M.A. 1990. Sesasedi sa katlego. Johannesburg: MacMillan-Boleswa.

KGATLA, P.M. 2000. Kgolo, Tšwelopele le Katlego ya Kanagelokopana ya Sepedi (1951-1999). Pretoria: University of Pretoria. (D.Litt. thesis.)

LA COUR, T. \& MOGENSEN, H. 1971. The murder book: an illustrated history of the detective story. London: Allen \& Unwin.

LAZARUS, A. \& SMITH, H.W. 1983. A glossary of literature and composition. Illinois: National Council of Teachers.

MACHIU, J.Z.O. 1995. Nnete Fela - Northern Sotho detective story: a critical evaluation. Pretoria: Vista University. (M.A. dissertation.)

MAGAPA, N.I. 1997. P.M. Lebopa: Papetšo ya dikanegelotseka tša Lebopa. Pretoria: University of Pretoria. (M.A. dissertation.)

MAHOLE, B.F. 2002. Lenong la Gauta: Padi ya botseka. Pretoria: University of Pretoria. (M.A. dissertation.)

MAMPURU, D.M. 1986. A critical assessment of Lenong la Gauta as a detective novel (story). South African journal of African languages, 6(4):149-210.

MAMPURU, D.M. 1991. Makhura' Lefehlo. Pretoria: De Jager-HAUM.

MANDEL, E. 1984. Delightful murder: a social history of the detective story. Minneapolis: University of Minnesota Press.

MAPHOTO, A.N. 1983. Leabela le a fetiša. Braamfontein: Sasavona.

MAPUTLA, S.M. 1991. Ga se nna mmolai. Pretoria: Van Schaik.

MATLALA, W.T. 1969. Hlokwa-la-tsela. Johannesburg: Afrikaanse Pers.

MOJALEFA, M.J. 1995. Ntlhahle ya Boraro. Pretoria: University of Pretoria. (B.A.: Sepedi 303.)

MOJALEFA, M.J. 1998. Kepisi ya lephodisa. Lebowakgomo: Mogopo.

MOJALEFA, M.J. 2001. Classification of detective Sepedi stories. South Africa journal of African languages, 21(3):220-225.

MOLOTO, D.N. 1962. Tšhipu e rile ke lebelo. Bloemfontein: Via Afrika.

MOLOTO, V.M. 1983. Letlapa la Bophelo. Pretoria: Rostrum.

MOTHAPO, M.T. 1986. Etshwang Mare. Pretoria: Van Schaik.

MOTUKU, H.Z. \& RAMOKGOPA, H.H. 1972. Nka se lebale. Bloemfontein: Via Afrika.

MPHAHLELE, L.L. 1984. Lenong la Gauta by H.D.N. Bopape. South African journal of African languages, 2(2):9-13.

MPHAHLELE, M.C. 1984. Letsogo la molao. Pretoria. De Jager-HAUM.

MURCH, A.E. 1968. The development of the detective novel. London: Owen.

NGOEPE, J.D.N. 1980. Seswai sa Ditabanatodi. Pretoria: Van Schaik.

PALMER, J. 1978. Thrillers: genesis and structure of a popular genre. London: Arnold.

PRINCE, G. 1988. A dictionary of narratology. Lincoln: University of Nebraska Press.

RAMAILA, E.M. 1951. Molomatsebe. Pretoria: Van Schaik.

SAYERS, D. 1989. Aristotle on detective fiction. (In Winks, R.W., ed. Detective fiction: a collection of critical essays, Englewood Cliffs: Prentice-Hall. p. 25-34.)

SERUDU, M.S. 1984. Lenong la Gauta by H.D.N. Bopape. South African journal of African languages, 2(2):14-19.

SERUDU, M.S. 1985. Letlapa la Bophelo by M.V. Moloto. South African journal of African languages, 5(3):115-125. 
SHAPIRO, W.E. 1979. The new book of knowledge. New York: Growlier.

SHIPLEY, J.T. 1970. Dictionary of world literary Terms. Boston: Shipley.

SUITS, B. 1985. The detective story: a case study of games in literature. Canadian reviews of comparative literature, 12(2):200-219.

TLOOKE, A.M. 1987. Lerole la Bjaša. Pretoria: Van Schaik.

TODOROV, T. 1988. The typology of detective fiction. (In Lodge, D., ed. Modern criticism and theory: a reader. Burnt Mill: Longman. p. 157-165.)

TURCO, L. 1999. The book of literary terms. Hanover: University Press of New England.

WALES, K. 1989. A dictionary of stylistics. London: Longman.

WINKS, R.W. 1980. Detective fiction: a collection of critical essays. Englewood Cliffs: Prentice-Hall.

\section{Key concepts:}

character: detective

detective stories

evidence that reveals the mystery

identity: victim

investigation that reveals the mystery

mystery

name: criminal

\section{Kernbegrippe:}

bewyse wat die raaisel ontrafel

identiteit: slagoffer

karakter: speurder

naam: oortreder/misdadiger

ondersoek wat die raaisel ontrafel

raaisel

speurverhale 